\title{
Analisis Kecenderungan Survival Penderita HIV (+) dengan Terapi ARV Menggunakan Aplikasi Life Table
}

\author{
Munfaridah, Diah Indriani \\ Departemen Biostatiska dan Kependudukan FKM UNAIR \\ Fakultas Kesehatan Masyarakat Universitas Airlangga \\ Jl. Mulyorejo Kampus C Unair Surabaya 60115 \\ Alamat Korespondensi: \\ Munfaridah,munfaridahmuhaimin@gmail.com
}

\begin{abstract}
Survival analysis was a technique in statistical that used to analyze the data of an event, starting from the beginning to the end of the event and noted the timing of the events that have been determined, time was recorded in a day, week, month, or year. The purpose of this research was analyzed tendency survival with HIV positive of stage III to clinical stage AIDS. This research method used analytic observational with retrospective cohort design, analysis data used descriptive analysis and analysis of life table survival. The research used units of data population with inclution criteria, the first diagnosed with HIV (+) stage III at Dr. Kariadi Semarang Hospital from year 2008-2012, CD4 less from $200 \mathrm{sel} / \mathrm{mm} 3$ and consumed antiretroviral. The results showed a tendency survival of patients with HIV faster have been AIDS are low educational status 10 months, faster than on the status of higher education with decreased survival of 50\%; the age group over 40 years, faster of 35 months less than the age group less 40, with years with decreased survival of 25\%; HIV patients who started antiretroviral therapy with low CD4 counts, faster 7.5 months had been AIDS at the start of antiretroviral therapy with CD4 high, the chances of survival decrease by $60 \%$. Early detection of HIV must be done in order to support the prevention of AIDS.
\end{abstract}

Keywords: survival time, HIV, life table

\begin{abstract}
ABSTRAK
Analisis survival adalah teknik dalam ilmu statistika yang digunakan untuk menganalisis data suatu peristiwa, dimulai dari awal sampai akhir peristiwa dan dicatat waktu terjadinya peristiwa yang sudah ditentukan, waktu dicatat dalam hari, minggu, bulan, atau tahun. Tujuan penelitian ini adalah menganalisis kecenderungan survival penderita HIV positif dari stadium III sampai stadium klinis AIDS. Metode penelitian ini menggunakan observasional analitik dengan rancang bangun kohort retrospektif, dianalisis secara deskriptif dan survival life table. Penelitian ini menggunakan unit data dari populasi penderita HIV yang melakukan pemeriksaan di RSUP Dr. Kariadi Semarang tahun 2008-2012, dengan kriteria inklusi stadium III, jumlah CD4 kurang dari $200 \mathrm{sel} / \mathrm{mm}^{3}$ dan mengkonsumsi ARV. Hasil penelitian menunjukkan kecenderungan survival pasien HIV yang lebih cepat mengalami AIDS yaitu status pendidikan rendah 10 bulan, lebih cepat dari pada status pendidikan tinggi dengan penurunan survival 50\%; kelompok usia lebih dari 40 tahun, lebih cepat 35 bulan dari pada usia kurang dari 40 tahun dengan penurunan survival 25\%; penderita HIV yang memulai terapi ARV dengan jumlah CD4 rendah, lebih cepat 7,5 bulan mengalami AIDS dari pada yang memulai terapi ARV dengan CD4 tinggi, peluang penurunan survival sebesar 60\%. Deteksi dini HIV harus dilakukan agar dapat mendukung pencegahan terjadinya AIDS.
\end{abstract}

Kata kunci: survival, HIV, life table

\section{PENDAHULUAN}

Analisis survival merupakan teknik dalam ilmu statistika yang digunakan untuk menganalisis data, dengan tujuan untuk melihat hasil dari variabel yang terlibat atau berpengaruh pada suatu peristiwa dalam hidup manusia. (Kleinbaum, 2011).
Waktu terjadinya peristiwa dalam observasi dicatat dalam hitungan hari, minggu, bulan, atau tahun, misalnya waktu survival yang dihitung dari awal pasien terdiagnosa penyakit tertentu sampai pasien mengalami kekambuhan, kematian atau kesembuhan akibat penyakit tersebut (Kleinbaum, 2011). 
Kegiatan statistika salah satunya adalah meramalkan harapan hidup seseorang atau menghitung waktu yang dibutuhkan seseorang dalam mempertahankan keadaan dirinya untuk tetap hidup dan tidak mengalami kekambuhan pada penyakit yang dideritanya. Perhitungan waktu tersebut dapat menggunakan sarana demografi seperti life table (Pollard, 1982).

Survival penderita HIV menurut ilmu epidemiologi dipengaruhi oleh beberapa faktor seperti faktor lingkungan, penjamu, dan agent (Potter dan Perry, 2005). Faktor lingkungan memang tidak secara langsung mempengaruhi waktu survival penderita HIV, namun sangat penting dalam mempengaruhi agent dan penjamu untuk meningkatkan waktu survival. Ketiga faktor tersebut saling berkaitan satu sama lain.

Penderita HIV dapat bertahan hidup lebih lama jika mengkonsumsi ARV, karena ARV bisa menekan perkembangan virus HIV. Jika penderita HIV patuh mengkonsumsi ARV maka waktu survival kemungkinan besar bisa sama dengan orang yang sehat tanpa penyakit HIV (Mandal, 2008).

Penelitian ini dibatasi pada faktor penjamu yaitu dengan variabel pendidikan, usia, dan jumlah CD4.

Human Imunodeficiency Virus (HIV) merupakan penyakit yang disebabkan oleh sejenis retrovirus, virus tersebut akan menyerang sistem imun pada manusia. Virus menggunakan DNA dari CD4 dan limfosit untuk mereplikasikan diri dan menghancurkan CD4 lama, setelah CD4 lama mati, maka akan menyerang CD4 yang baru. Jika jumlah CD4 dalam plasma semakin rendah maka dapat menyebabkan sistem imun juga semakin lemah (Nursalam, 2007).

Penderita HIV positif yang mempunyai sistem imun yang lemah maka mudah terinfeksi berbagai penyakit, keadaan ini biasa disebut infeksi opourtunistik dan merupakan penyebab utama munculnya tanda dan gejala AIDS (Nursalam, 2007).

Obat atau terapi untuk menyembuhkan penyakit HIV belum ada sampai saat ini, namun penyakit HIV dapat dikendalikan dengan mengonsumsi ARV secara rutin. Cara kerja ARV adalah menekan serta mengganggu proses replikasi virus dalam tubuh, dan CD4 dalam tubuh akan meningkat, maka proses terjadinya
AIDS dapat diperlambat dan angka kesakitan dan kematian akibat penyakit AIDS dapat dikurangi (WHO, 2015).

Perjalanan penyakit HIV terbagi ada 4 stadium klinis dengan waktu pencapaian pada setiap stadium klinis berbeda pada setiap penderita. Semua tergantung dari upaya yang dilakukan oleh penderita tersebut untuk mempertahankan status klinis penyakitnya agar berkembang pada stadium klinis AIDS atau kematian (Nasronudin, 2008).

Stadium klinis HIV adalah awalnya Infeksi yang dimulai dengan masuknya HIV ke dalam tubuh sampai tes antibodi terhadap HIV menjadi positif proses ini disebut window period dengan lama prosesnya satu sampai tiga bulan, bahkan ada yang berlangsung sampai enam bulan. Stadium kedua tanpa gejala (asimtomatik) berarti di dalam organ tubuh tidak menunjukkan gejala keadaan penyakit HIV proses ini dapat berlangsung selama 5 sampai 10 tahun (Nursalam, 2007).

Stadium ketiga pembesaran kelenjar limfe secara menetap dan merata hanya berlangsung selama satu bulan. Stadium keempat AIDS, keadaan ini disertai adanya berbagai jenis penyakit antara lain penyakit syaraf, infeksi sekunder dan lainnya yang biasa disebut infeksi oportunistik (Nursalam, 2007).

Berdasarkan laporan penanggulangan HIVAIDS Indonesia (2014) dari tahun 2005-2014, HIV banyak menginfeksi pada golongan usia 30-39 tahun dengan jumlah 15.816. Serta dari jumlah per 10.000 penduduk berdasarkan jenis kelamin, laki-laki 53,7\% lebih banyak menderita HIV dari pada perempuan $28,9 \%$ (Kemenkes RI, 2014).

Mengkonsumsi ARV pada penderita HIV akan sangat membantu untuk menurunkan jumlah virus dalam darah, dengan mengkonsumsi ARV secara rutin diharapkan penderita HIV mempunyai harapan hidup yang sama dengan orang normal yang tidak terinfeksi (Nasronudin, 2008).

Jika ART tidak dilakukan secara tepat dan rutin maka CD4 secara perlahan akan menurun dalam beberapa tahun dengan laju penurunan CD4 yaitu 1,5 sampai 2,5 tahun. HIV tanpa pengobatan ARV rata-rata kemampuan bertahan setelah CD4 turun kurang dari $200 \mathrm{sel} / \mathrm{mm}^{3}$ 
adalah 3,7 tahun sebelum penyakit pasien HIV berkembang dalam keadaan stadium AIDS (Mandal, 2008).

Tujuan dalam penelitian ini yaitu menganalisis kecenderungan survival penderita HIV positif yang menjalani terapi ARV menggunakan aplikasi life table, penelitian ini tidak meneliti pengaruh antar variabel terhadap waktu survival.

Hasil dari penelitian ini diharapkan dapat memberikan informasi bagi masyarakat tentang manfaat konsumsi ARV pada penderita HIV positif sebagai solusi dalam pengendalian penyakit AIDS.

\section{METODE PENELITIAN}

Jenis penelitian ini adalah penelitian observasional analitik dengan rancang bangun penelitian kohort retrospektif, penelitian ini menggunakan data sekunder yaitu catatan rekam medik pasien yang didiagnosa positif HIV dimasa lalu dan dianalisis sampai Bulan Januari 2016.

Tempat penelitian dilakukan di RSUP Dr. Kariadi Semarang. Waktu penelitian dimulai pada Bulan Agustus 2015 sampai Januari 2016, pengambilan data dilakukan pada bulan November 2015. Penelitian survival penderita HIV dianalisis dalam interval waktu 5 tahun dengan pencatatan waktu terjadinya event (AIDS) dengan satuan bulan.

Penelitian ini menggunakan unit data dari populasi penderita HIV positif yang melakukan pemeriksaan ke RSUP Dr. Kariadi Semarang pada tahun 2008-2012. Unit data penelitian dengan kreteria inklusi adalah pasien yang didiagnosa positif HIV pertama kali pada stadium klinis III, jumlah CD4 kurang dari $200 \mathrm{sel} / \mathrm{mm}^{3}$ serta menjalani terapi antiretroviral (ARV). Variabel yang diteliti adalah pendidikan, usia, dan jumlah CD4.

Pengumpulan data dilakukan dengan cara menyeleksi data dari rekam medik pasien dan dilakukan seleksi sesuai dengan kriteria inklusi sampel penelitian. Data yang sudah didapat langsung dimasukkan dalam sistem komputer yang sudah diatur dan ditentukan variabel yang akan dianalisis. Analisis data dalam penelitian ini menggunakan dua cara yaitu analisis deskriptif dan analisis survival life table.

\section{HASIL}

\section{Karakteristik Penderita HIV}

Berdasarkan hasil pengumpulan data dan seleksi data didapatkan objek penelitian sebanyak 24 penderita HIV.

Keadaan responden berdasarkan usia, pendidikan, dan jumlah CD4 saat memulai terapi ARV dapat dilihat pada Tabel 1.

Penderita HIV yang memiliki status pendidikan terakhir tidak tamat sekolah sebanyak 4 responden $(16,7 \%)$, status pendidikan terakhir SD yaitu sebanyak 4 responden (16,7\%), dengan status pendidikan terakhir SMP yaitu sebanyak 6 responden $(25 \%)$, status pendidikan terakhir SMA yaitu sebanyak 8 responden $(33,3 \%)$, dan status pendidikan terakhir perguruan tinggi (PT) yaitu sebanyak 2 responden $(8,3 \%)$.

Berdasarkan kelompok usia, kelompok usia 20-29 tahun sebanyak 7 responden $(29,17 \%)$, kelompok usia 30-39 tahun yaitu sebanyak 9 penderita HIV (41,56\%), dan kelompok usia lebih dari sama dengan 40 tahun yaitu sebanyak 7 responden $(29,17 \%)$,

Berdasarkan jumlah CD4 awal waktu mengonsumsi ARV menunjukkan bahwa penderita HIV yang terdiagnosa HIV positif dan memulai terapi ARV dengan jumlah CD4 rendah yaitu sebanyak 17 responden (70,8\%), dan yang memulai terapi ARV dengan jumlah CD4 tinggi yaitu sebanyak 7 responden $(29,2 \%)$.

Tabel 1. Distribusi karakteristik penderita HIV penderita HIV (+) di RSUP Dr. Kariadi Semarang

\begin{tabular}{|c|c|c|c|}
\hline \multicolumn{2}{|c|}{ Karakteristik Penderita HIV } & \multirow{2}{*}{$\begin{array}{c}\mathbf{N} \\
4\end{array}$} & \multirow{2}{*}{$\begin{array}{c}\% \\
16,7\end{array}$} \\
\hline \multirow{5}{*}{ Pendidikan } & Tidak sekolah & & \\
\hline & SD & 4 & 16,7 \\
\hline & SMP & 6 & 25,0 \\
\hline & SMA & 8 & 33,3 \\
\hline & PT & 2 & 8,3 \\
\hline \multirow{3}{*}{ Usia } & 20-29 tahun & 7 & 29,17 \\
\hline & 30-39 tahun & 9 & 41,56 \\
\hline & $\geq 40$ tahun & 7 & 29,17 \\
\hline \multirow{2}{*}{$\begin{array}{l}\text { Kategori Jumlah } \\
\text { CD4 }\end{array}$} & Rendah & 17 & 70,8 \\
\hline & Tinggi & 7 & 29,2 \\
\hline
\end{tabular}




\section{Kecenderungan Survival Penderita HIV}

Kecenderungan survival penderita HIV dari stadium klinis III sampai mengalami perkembangan stadium AIDS yaitu:

Berdasarkan status pendidikan terakhir, penderita HIV yang berstatus pendidikan PT (Perguruan Tinggi) memiliki waktu survival lebih lama, peluang waktu berkembangnya HIV dari stadium III sampai stadium AIDS terjadi dalam waktu 60 bulan.

Penderita HIV dengan status tamat pendidikan tidak sekolah dan SD memiliki waktu survival yang sama yaitu 10 bulan berkembang menjadi stadium AIDS. Penderita HIV dengan status pendidikan terakhir SMP mempunyai waktu survival 23,33 bulan untuk berkembang pada stadium AIDS, penderita HIV dengan status pendidikan terakhir SMA memiliki waktu survival 25 bulan untuk berkembang pada stadium AIDS.

Penderita HIV dengan berdasarkan kelompok usia, kelompok 30-39 tahun memiliki waktu survival 60 bulan untuk berkembang pada stadium AIDS. Penderita HIV dengan kelompok usia 20-29 tahun memiliki waktu survival yaitu 55 bulan waktu untuk berkembang pada stadium AIDS dan pada penderita HIV yang berusia lebih dari 40 tahun hanya memiliki waktu survival 35 bulan untuk berkembang pada stadium AIDS.

Berdasarkan jumlah CD4 penderita HIV yang memulai terapi ARV dengan CD4 tinggi memiliki waktu survival lebih lama yaitu 12,5 bulan dari pada penderita HIV yang memulai terapi ARV dengan jumlah CD4 rendah yaitu 7,5 bulan.

\section{Grafik Fungsi Survival}

Garis fungsi survival life table menggambarkan waktu proses terjadinya perkembangan stadium klinis HIV dari stadium III sampai AIDS. Semakin turun garis pada grafik fungsi survival maka menggambarkan keadaan penderita HIV yang mendekati pada stadium AIDS atau peluang penderita HIV stadium III untuk menjadi stadium AIDS semakin besar dan berlaku sebaliknya. Perhitungan besaran peluang terjadinya AIDS dinyatakan dalam bentuk prosentase.

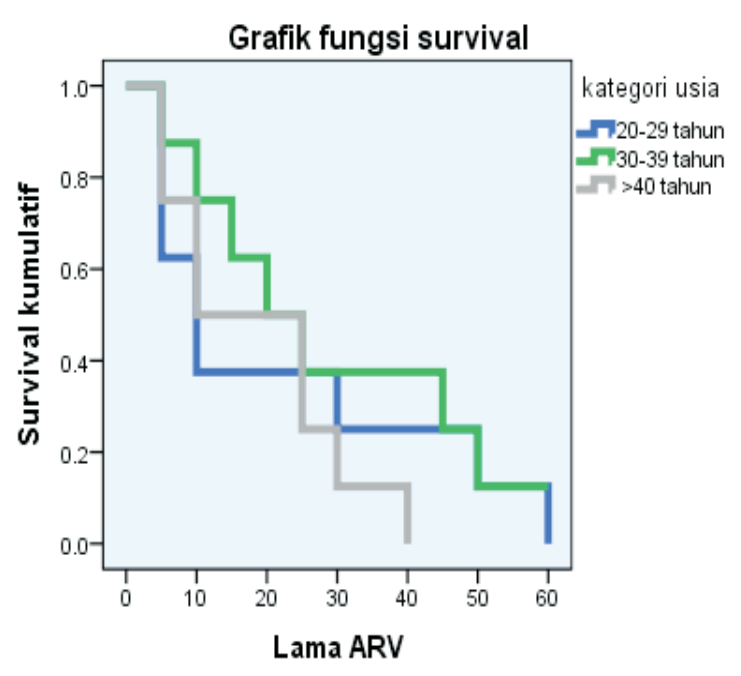

Gambar 1. Grafik fungsi survival status pendidikan penderita HIV $(+)$.

Gambar 1 menunjukkan bahwa garis fungsi survival pada penderita HIV dengan status pendidikan terakhir Perguruan Tinggi (PT), cenderung lebih survive dari pada penderita HIV yang memiliki status pendidikan terakhir (Tidak tamat sekolah, SD, SMP, SMA). Pada 20 bulan pertama setelah diagnosa positif HIV tidak menunjukkan adanya penurunan survival atau masih $100 \%$ dalam hal ini berarti belum ada tanda untuk mengalami AIDS. Pada bulan berikutnya terjadi penurunan survival yang sangat drastis yaitu mencapai 50\%, kemudian garis survival stabil pada kisaran waktu 22 bulan dan dapat mencapai waktu lebih dari 5 tahun penderita HIV tidak mengalami AIDS.

Penderita HIV dengan status pendidikan terakhir SD dan tidak tamat sekolah memiliki peluang terjadinya AIDS lebih cepat dari pada penderita HIV yang memiliki status pendidikan tinggi yaitu mengalami penurunan survival $50 \%$ pada kisaran waktu 10 bulan pertama setelah didiagnosa positif HIV dan menjalani terapi ARV.

Gambar 2 menunjukkan grafik fungsi survival berdasarkan kategori usia, diketahui bahwa penderita HIV pada kelompok usia - 30 39 tahun memiliki survival lebih lama yaitu mencapai waktu 60 bulan atau mencapai interval waktu lebih dari 5 tahun. Peluang berkembangnya kelompok usia 30-39 tahun pada stadium AIDS adalah $5 \%$ terjadi pada kisaran waktu 5 bulan pertama setelah didiagnosa positif HIV. 


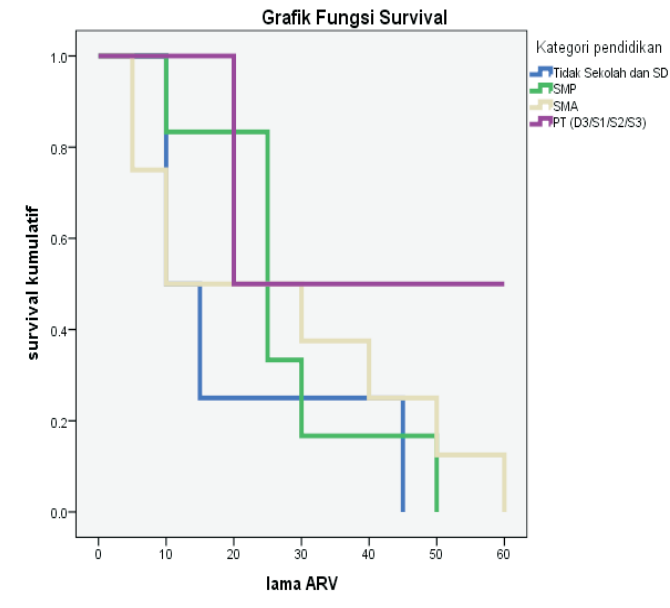

Gambar 2. Grafik fungsi survival berdasarkan kelompok usia penderita HIV $(+)$.

Survival penderita HIV pada kelompok usia lebih dari 40 tahun mengalami penurunan survival $25 \%$ pada 5 bulan pertama setelah didiagnosa positif HIV. Penurunan pada bulan berikutnya terus menurun hingga stadium klinis berkembang menjadi AIDS dengan median waktu 35 bulan.

Kelompok usia 20-29 tahun berpeluang mengalami AIDS dengan penurunan waktu survival $45 \%$ terjadi pada 5 bulan pertama setelah didiagnosa positif HIV, bertambahnya lama waktu mengonsumsi ARV setelah waktu mengonsumsi ARV bertambah lama maka pada 10 bulan berikutnya keadaan lebih labil dibandingkan dengan kelompok usia lebih dari 40 tahun.

Gambar 3 menunjukkan garis fungsi survival penderita HIV berdasarkan jumlah CD4. Penderita yang memulai terapi dengan jumlah CD4 awal rendah, menunjukkan garis fungsi survival yang lebih cepat untuk mengalami AIDS.

Peluang terjadinya AIDS ditandai dengan penurunan waktu survival yaitu mencapai $35 \%$, terjadi pada kisaran waktu 5 bulan pertama setelah didiagnosa positif HIV dan memulai terapi.

Penderita HIV dengan jumlah CD4 tinggi ditunjukkan dengan garis fungsi survival yang lebih stabil dan dapat mencapai interval waktu 5 tahun atau 60 bulan. Meskipun pada penderita HIV yang memulai terapi ARV dengan jumlah

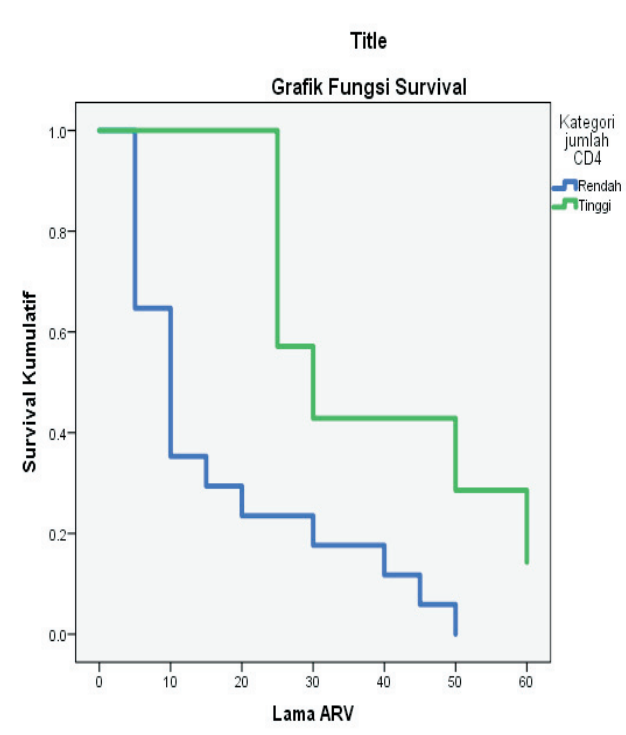

Gambar 3. Grafik fungsi survival golongan jumlah CD4 penderita HIV (+).

CD4 tinggi. setelah 30 bulan menjalani terapi ARV mengalami penurunan waktu survival yang mencapai $40 \%$, namun dapat tetap stabil pada waktu lebih dari 30 bulan.

Penderita HIV yang memulai terapi dengan jumlah CD4 rendah berpeluang lebih cepat untuk menjadi AIDS yaitu mencapai 30, mengalami penurunan waktu survival terjadi pada 5 bulan pertama setelah didiagnosa positif HIV.

\section{PEMBAHASAN}

\section{Pendidikan}

Penderita HIV yang memiliki status pendidikan terakhir tidak tamat sekolah dan SD memiliki survival 10 bulan lebih cepat untuk berkembang ke stadium klinis AIDS dan penurunan survival mencapai $50 \%$. Hal tersebut lebih cepat jika dibandingkan pada penderita HIV yang memiliki status pendidikan terakhir tinggi.

Peluang berkembangnya stadium klinis pada penderita HIV dengan status pendidikan terakhir perguruan tinggi (PT), dapat diketahui bahwa dalam interval waktu 5 tahun dan sampai penelitian ini selesai, penderita HIV masih tetap survive pada stadium klinis yang sama dari awal didiagnosa HIV positif sampai akhir penelitian.

Pendidikan memang bukan variabel yang langsung berpengaruh pada peningkatan stadium 
klinis, namun status pendidikan merupakan komponen penting pada penderita HIV dalam proses penerimaan informasi terkait penyakit HIV dan upaya pengendaliannya.

Penelitian ini adalah data sekunder maka untuk mengukur pengetahuan hanya dilihat dari status pendidikan akhir, semakin tinggi tingkat pendidikan diasumsikan juga memiliki pengetahuan yang baik.

Penerimaan informasi yang salah juga dapat membentuk sikap yang salah, hal tersebut terjadi karena salah satu pembentuk sikap individu adalah pengetahuan yang diperolehnya (Yusuf, 2006).

Penelitian yang dilakukan oleh Ubra (2012), menunjukkan bahwa status pendidikan memiliki hubungan yang bermakna yaitu terkait sikap kepatuhan penderita HIV dalam mengonsumsi ARV. Status pendidikan yang tinggi memiliki proporsi kepatuhan minum ARV 20 kali dibandingkan dengan status pendidikan yang rendah. Jika hasil penelitian dikaitkan dengan teori dan hasil penelitian lain bahwa penderita HIV yang memiliki status pendidikan terakhir yang tinggi akan lebih paham dalam upaya pengendalian AIDS, upaya itu dilakukan dengan cara mengonsumsi ARV rutin.

Konsumsi ARV secara rutin maka dapat menekan virus HIV dalam darah dan berpengaruh pada peningkatan jumlah CD4. Meningkatnya jumlah CD4 maka juga akan berpengaruh pada penguatan sistem imun dan infeksi oportunistik dapat kendalikan serta perkembangan stadium klinis III ke stadium klinis AIDS dapat terjadi lebih lama (WHO, 2006).

Berdasarkan hasil penelitian yang dibandingkan dengan teori dan hasil penelitian lain, maka dapat diketahui bahwa penderita HIV yang dapat menerima informasi dengan baik terkait pengendalian dan pencegahan AIDS, maka juga dapat bersikap baik dalam upaya pengendalian AIDS. Sikap yang terbentuk adalah seperti konsumsi ARV secara rutin, dapat mengendalikan penyebaran virus HIV, dan memeriksakan kesehatan secara rutin.

Jika semua penderita HIV memiliki pengetahuan baik tentang penyakitnya, maka sikap patuh mengonsumsi ARV dan upaya pencegahan perkembangan penyakit HIV juga akan baik. Upaya pengendalian AIDS jika dilakukan dengan baik maka kesakitan akibat terjadinya AIDS juga dapat dikurangi dan penderita HIV dapat tetap hidup produktif serta harapan hidup bisa sama seperti orang yang sehat.

\section{Usia}

Penderita HIV yang berusia 30-39 tahun merupakan kelompok usia yang memiliki kecenderungan survival paling lama untuk mengalami perkembangan stadium klinis III ke stadium AIDS, dengan pencapaian waktu 60 bulan. Hal ini lebih lama dari pada kelompok usia 20-29 tahun dan usia lebih dari sama dengan 40 tahun. Waktu pencapaian 60 bulan berarti penderita HIV yang masih survive pada stadium III dari awal didiagnosa sampai akhir penelitian.

Pada kelompok usia lebih dari 40 tahun memiliki peluang lebih cepat berkembang pada stadium klinis AIDS dalam waktu 35 bulan dengan penurunan waktu survival $25 \%$.

Hal ini kemungkinan besar pada kelompok usia 30-39 tahun merupakan kelompok usia yang masih produktif memiliki daya imun yang kuat serta motivasi yang kuat, sehingga upaya untuk pengendalian AIDS juga relatif lebih bagus, pada kelompok usia yang muda mungkin lebih memiliki emosi yang masih labil dalam menanggapi penyakitnya meskipun pada usia muda daya imunitas dalam tubuh masih relatif kuat.

Pada kelompok usia lebih dari 40 tahun mempunyai daya imun yang lebih rentan terhadap penyakit, karena pada usia tua juga terjadi proses alamiah penurunan fungsi dalam tubuh dan penurunan daya ingat sehingga untuk mengonsumsi ARV bisa saja tidak rutin karena faktor daya ingat yang berkurang.

Menurut penelitian Liu H (2005) di Cina bahwa untuk mendapatkan keberhasilan pengobatan ARV diperlukan tingkat kepatuhan minimal 95\% yang berarti hanya lupa atau telat minum tiga dosis perbulan dengan jadwal dua kali sehari, hanya $81 \%$ menunjukkan virus dalam darah yang tidak terdeteksi, sehingga jika pasien lupa minum ARV maka pengobatan ARV menjadi tidak efektif (Anggraeni, 2010).

Penelitian oleh Viard dkk (2010), menunjukkan bahwa, usia yang lebih tua lebih lama untuk meningkatkan CD4 dalam darah 
dibandingkan yang berusia muda sehingga peningkatan stadium klinis AIDS dapat terjadi lebih cepat. Hal tersebut karena jika seseorang didiagnosa HIV positif pada usia tua kemungkinan peluang untuk terjadinya infeksi oportunistik lebih besar dan kepatuhan minum obat juga menurun.

\section{Jumlah CD4}

Penderita HIV memulai terapi ARV dengan jumlah CD4 tinggi cenderung lebih lama untuk berkembang penyakitnya pada stadium klinis AIDS yaitu dalam median waktu 27,5 bulan. Jika dibandingkan dengan penderita HIV yang memulai terapi ARV dengan jumlah CD4 rendah sangatlah jauh perbandingannya yaitu hanya memiliki waktu survival 5 bulan dengan penurunan waktu survival $35 \%$ dalam 5 bulan pertama memulai ARV.

Kadar CD4 sel yang rendah pada awal melakukan terapi ARV dikaitkan dengan rendahnya peningkatan CD4. Berdasarkan hasil penelitian Kaufmann (2005) menunjukkan bahwa jumlah CD4 yang rendah pada awal terapi ARV lebih sulit meningkatkan jumlah CD4.

Hasil studi yang dilakukan oleh Boris dkk (2012), selama 7 tahun, juga menunjukkan bahwa orang dengan jumlah CD4 rendah di bawah $50 \mathrm{sel} /$ mm3 mempunyai risiko empat kali untuk tidak mengalami peningkatan CD4 $>200 \mathrm{sel} / \mathrm{mm}^{3}$.

Berdasarkan hasil penelitian dan teori maka dapat disimpulkan bahwa pemeriksaan HIV lebih awal maka dapat mendukung suksesnya dalam terapi ARV, karena jika HIV diketahui lebih dini dengan stadium yang masih awal kemungkinan CD4 juga masih tinggi dan virus dalam darah masih rendah. Jika pengendalian terjadinya AIDS dilakukan dengan baik maka harapan dan kualitas hidup penderita HIV juga akan lebih baik.

Penderita HIV juga harus melakukan upaya apa saja agar penyakitnya tidak berkembang pada stadium klinis AIDS, karena pengendalian HIV tidak bisa dilakukan hanya dengan mengonsumsi ARV rutin. Penderita HIV meskipun sudah rutin dalam minum ARV terkadang juga masih berpeluang untuk mengalami kegagalan imunologi, maka dari itu juga harus dilakukan pemeriksaan yang mendukung seperti pemeriksaan CD4 dan pemeriksaan untuk memantau jumlah virus HIV yang ada dalam darah.

Menurut hasil penelitian Hygleman (2007), pemeriksaan CD4 sebaiknya diulang setiap 3-6 bulan untuk pasien yang belum pernah ART yang sudah ART setiap 4 bulan agar perkembangan AIDS dapat dipantau dan terapi ARV dapat dilakukan secara efektif.

Menurut hasil penelitian Sugiharti (2014), menunjukkan bahwa ada beberapa faktor yang menyebabkan rendahnya persentase konsumsi ARV pada penderita HIV positif, antara lain tingginya biaya berobat yang dikeluarkan penderita HIV (seperti biaya transportasi, dan pemeriksaan CD4, dan pemeriksaan jumlah virus HIV dalam darah), efek samping dari obat ARV, kejenuhan dan stigma dari lingkungan, hal ini membuat sebagian besar ODHA merasa kurang nyaman dalam minum obat ARV.

Hal ini berarti melakukan deteksi HIV dan periksa CD4 efektif untuk mendukung pengendalian AIDS, karena jumlah CD4 adalah salah satu indikator yang paling diandalkan untuk melakukan prognosis terapi ARV dan jika HIV (+) diketahui lebih dini maka dapat segera dilakukan implementasi lebih lanjut yang tepat agar peluang untuk terjadinya AIDS juga dapat dikendalikan.

\section{SIMPULAN DAN SARAN}

\section{Simpulan}

Kecenderungan survival penderita HIV yang memulai ART dengan jumlah CD4 rendah mengalami AIDS dalam rentan waktu 7,5 bulan, pada kelompok usia lebih dari 40 tahun waktu terjadinya AIDS dalam rentan waktu 35 dan waktu terjadinya AIDS pada penderita dengan status pendidikan rendah adalah 10 bulan.

Peluang terjadinya AIDS berdasarkan grafik fungsi survival pada pendidikan rendah adalah survival menurun $50 \%$ terjadi pada 10 bulan pertama setelah terdignosa positif HIV, pada kelompok usia lebih dari 40 tahun menurun $25 \%$ pada 5 bulan pertama setelah didiagnosa, dan penderita yang memulai terapi ARV dengan jumlah CD4 rendah mengalami penurunan waktu survival sebanyak $30 \%$ pada 5 bulan pertama didiagnosa positif HIV. 


\section{Saran}

Deteksi dini HIV penting dilakukan dalam mendukung pencegahan atau memperlambat terjadinya AIDS. Demikian juga perlu peningkatan pengetahuan penderita HIV tentang cara peningkatan daya tahan tubuh melalui pengobatan ARV maupun pola kehidupan sehat sehari-hari.

\section{DAFTAR PUSTAKA}

Anggraeni, N.D. 2010. Ketahanan hidup satu tahun pasien hiv/aids dengan pengobatan regimen arv lini pertama berdasarkan jumlah CD4 sebelum pengobatan ARV di RSPI prof. $d r$. Sulianti saroso tahun 2005-2010. Tesis. Jakarta: FKM-UI Program Magister Ilmu Kesehatan Masyarakat.

Boris, J., Danielle, P., Musie, G., Carmen, C., Marcus, A., Henry, S., Richard, AM., and Bruce, DW. 2012. Factors predicting discordant virological and immonological responses to antiretroviral therapy in HIV-1 clade $\mathrm{C}$ infected Zulu/Xhosa in south Africa. PLOSO ONE (7)

Kemenkes RI. 2006. Pedoman nasional perawat, Dukungan dan Pengobatan bagi ODHA. In Buku pedoman untuk petugas kesehatan dan petugas lainnya. Jakarta: Departemen Kesehatan Republik Indonesia.

Highleyman, L. 2009. Large Meta-analysis Indicates Antiretroviral Therapy Works as Well for Women as for Men. HIV and hepatitis.com, 20 Februari.

Kaufmann,GR., Hansjakob, F., Bruno, L., Luc, P., Milos, O., Pietro V. 2005.Characteristics, determinants, and clinical relevance of $\mathrm{CD} 4 \mathrm{t}$ cell recovery to lebih dari 500 cells $/ \mathrm{ml}$ in $\mathrm{HIV}$ type 1-infected individuals receiving potent antiretroviral therapy. Clinical infectious diseases, 41, pp. 361-72.

Kemenkes RI. 2014. Laporan perkembangan HIV-AIDS di Indonesia tahun 2014. In Data HIV-AIDS. Jakarta: Kementerian Kesehatan RI. p.113.
Kleinbaum, D.G. 2011. Survival analysis a self learning text. $3^{\text {rd }}$ ed. Atlanta, Georgia: Springer.

Liu, H.H., Yang, X.L., Wang, N., Liu, H.B. 2005. Men who have sex with men and HIV/Sexually transmitted desease control in china. cell res, 15(11-12), pp. 858-64.

Mandal, B.K. 2008. Penyakit Infeksi. Lecture Notes. $6^{\text {th }}$ ed. Jakarta: Erlangga.

Nasronudin, 2008. HIV dan AIDS. Pendekatan biologi molekuler, klinis dan social. Surabaya: Airlangga University Press.

Nursalam. 2007. Asuhan keperawatan pada pasien terinfeksi HIV-AIDS. Jakarta: Salemba Medika.

Pollard, A.H., Yusuf, F. 1982. Demographic teachniques. Australia: Pergamon Press.

Potter dan Perry. 2005. Fundamental Keperawatan ed 4. Jakarta: EGC.

Sugiharti, H.Y. 2014. Gambaran Kepatuhan orang dengan HIV-AIDS (ODHA) dalam minum obat ARV di kota Bandung, Provinsi Jawa Barat tahun 2011-2012. International Journal of Infectious Diseases, 12, pp. 325-31.

Ubra, R. 2012. Faktor-faktor yang berhubungan dengan kepatuhan pengobatan minum ARV pada pasien HIV di Kabupaten Mimika Provinsi Papua tahun 2012. Tesis. Jakarta: Universitas Indonesia Universitas Indonesia.

Viard, JP., Amanda, M., Antonio, C., Ole, K., Birgit, R., George, P., Norbert, V. 2010. The Journal of Infectious Diseases, 4(183), pp. 1290-94.

WHO. 2006. Antiretroviral therapy for HIV infection in adults and adolescent. In recommendations for a public health.

WHO. 2015. Guideline on when to start antiretroviral therapy andon pre exposure. Switzerland: Publications of the World Health.

Yusuf, S. 2006. Psikologi perkembangan anak dan remaja. Bandung: PT. Remaja Rosda Karya. 